ÉtICA e FILOSOFIA POLÍTICA

\title{
O trabalho do impróprio e os afetos da flexibilização
}

\author{
The Labor of Improper and \\ the Affections of Flexibilization
}

* Vladimir P. Safatle

\begin{abstract}
Resumo: Trata-se de discutir a centralidade do trabalho como categoria de reconhecimento através da problematização de sua natureza disciplinar. Isto nos levará a um duplo movimento: primeiro, a categoria de trabalho em Marx será relida à luz não apenas da temática da espoliação econômica da mais-valia, mas também da espoliação psíquica das relações de estranhamento (unheimlichkeit) entre sujeito e objeto; segundo, as modificações recentes no mundo do trabalho e as modalidades de sofrimento psíquico a elas associadas serão interpretadas a partir do impacto social de tal forma de espoliação.
\end{abstract}

Palavras-chave: Depressão. Flexibilização. Trabalho. Reconhecimento. Marx.

\begin{abstract}
This article aims to discuss the role of labor as a model of recognition, taking into account the criticism about its disciplinary nature. Two movements are here presented: first, the notion of labor on Marx will be reinterpreted from the standpoint not just of the theme of economical spoliation of plus-value, but also from the standpoint of psychic spoliation of estrangement (unheimlichkeit) between subject and object; second, the contemporary modifications in the universe of labour and the modes of psychic suffering associated of it will be interpreted upon the social impact of such another form of spoliation. Keywords: Depression. Flexibilization. Labor. Recognition. Marx.
\end{abstract}

Fazer coisas que não sabemos

o que são.

(THEODOR ADORNO)

\footnotetext{
* Professor Livre-Docente do Departamento de Filosofia da Universidade de São Paulo (USP). Doutor em Filosofia pela Universidade Paris VIII. Bolsista de produtividade do CNPq. <vsafatle@yahoo.com>.
} 


\title{
Introdução
}

T Tá uma conhecida história narrada por Heródoto a respeito de certa 1 rebelião de escravos do povo Cita. Na ausência de seus senhores, os escravos rebelaram-se, demonstrando grande bravura nas lutas de resistência. Sua força e desejo de liberdade pareciam intransponíveis, isto até que um dos Citas inventou o moderno Departamento de Recursos Humanos e as primeiras técnicas de psicologia do trabalho. Munido de seu conhecimento recém adquirido, o Cita gritou no meio da luta:

\begin{abstract}
Vedes, homens da Cítia, o que fazemos! Lutando assim com nossos escravos, eles nos matam e nos tornamos menos numerosos, e nós os matamos e portanto nos restam menos escravos às nossas ordens. Opino, portanto, no sentido de abandonarmos nossas lanças e arcos e irmos combatê-los empunhando cada um de nós um chicote dos que usamos com os cavalos. Enquanto eles nos virem armados, julgar-se-ão iguais a nós, vendo-nos com chicotes em vez de armas, eles compreenderão que são nossos escravos; percebendo isto, não resistirão ${ }^{1}$.
\end{abstract}

E assim foi; ao virem os chicotes e ouvirem seu barulho, o medo quebra a revolta dos escravos e estes fogem para acabar por retornar à sua antiga condição. O que o Cita em questão descobriu em situação de guerra foi o uso político da força disciplinar do trabalho, a maneira com que o instrumento de trabalho era a encarnação de um princípio de sujeição capaz de quebrar vontades e perpetuar a condição de servidão. Não era possível combater os escravos rebelados, mas era possível explorar a potência da internalização da sujeição, do desejo mudo de submeter-se à disciplina e preservar a autoridade que estava encarnada na visão de um instrumento capaz de sintetizar as relações servis. Tais sujeitos foram produzidos por relações determinadas de trabalho e autoridade; eles constituíram a partir delas suas fantasias, seu universo psíquico e seu circuito de afetos.

Mesmo lutando pela liberdade, algo neles nunca poderia se voltar contra o que não era exatamente a imagem de seus senhores, mas o instrumento que organiza o tempo do trabalho, o lugar que cada um deveria ocupar com suas funções específicas, o ritmo do corpo, a sensação psicológica de dever cumprido e o regime de atenção. Mesmo revoltando-se contra a figura imaginária de autoridade, eles continuavam presos à determinação simbólica da disciplina. Eles poderiam se rebelar contra as representações da autoridade, mas não contra a estrutura, com sua ordem, suas determinações. Bastou que tal determinação simbólica se

HERODOTO. História, Brasília: Editora da UnB, 1985, p. 202. 
encarnasse no chicote para que o ímpeto da rebelião desaparecesse. Se o Cita que teve tal intuição pode ser elevado a patrono dos Departamentos de Recursos Humanos de nossas grandes empresas é por ele compreender como a verdadeira sujeição se constrói, principalmente, através da mobilização libidinal das estruturas disciplinares em circulação no universo do trabalho.

\section{Dominação pelo trabalho}

Mas, se este for o caso, poderíamos nos perguntar se o trabalho seria completamente indissociável da expressão de tais estruturas disciplinares ${ }^{2}$. Faria sentido organizar a crítica do trabalho alienado assumindo como pressuposto a possibilidade de pensar um trabalho vivo portador de promessas emancipatórias, ou seria o caso de dar um passo além a fim de, pura e simplesmente, criticar o trabalho como figura historicamente específica da ação social, figura esta a ser superada em uma sociedade reconciliada? Sabemos como, no interior da filosofia social moderna, o trabalho nunca foi apenas uma questão de produção de riqueza e de valor. Ao menos desde Hegel, ele é compreendido como uma estrutura fundamental de reconhecimento social, mas não foram poucos aqueles que colocaram radicalmente em questão a possibilidade dele ser um modelo de ação que não se reduziria à mera expressão de sujeição disciplinar, isto é, à lógica utilitarista que nos aprisiona indefinidamente à racionalidade instrumental. Lembremos, por exemplo, dessa maneira de definir o trabalho vinda de um de seus críticos mais consequentes, a saber, Georges Bataille:

O trabalho exige uma conduta em que o cálculo do esforço, relacionado à eficácia produtiva, é constante. Exige uma conduta razoável, em que os movimentos tumultuosos que se liberam na festa e, geralmente, no jogo, não são admitidos. Se não pudéssemos refrear esses movimentos, não poderíamos trabalhar, mas o trabalho introduz justamente a razão de refreá-los ${ }^{3}$.

Nesta citação, vemos Bataille insistir na existência de um modelo de cálculo, de mensuração, de quantificação derivado da lógica do trabalho

2 A respeito do universo do trabalho, dirá Foucault: "Esses métodos que permitem o controle minucioso das operações do corpo, que asseguram o assujeitamento constante de suas forças e que a eles impõem uma relação de docilidade-utilidade, é isto que podemos chamar de 'disciplinas'. Muitos procedimentos disciplinares existiam desde há muito - nos conventos, nas forças armadas e também nos ateliers. Mas as disciplinas, no curso dos séculos XVII e XVIII, transformaram-se em fórmulas gerais de dominação" (FOUCAULT, Michel. Surveiller et punir, Paris: Gallimard, 1975, p. 161).

3 BATAILLE, Georges. O erotismo, p. 64. 
e estranho à "improdutividade" desses modos de relação social que são a festa e o jogo. Tal modelo é indissociável da noção de "utilidade", assim como de um tempo no qual as atividades são medidas tendo em vista o cálculo dos esforços e investimentos, a "eficácia produtiva" com sua recusa ao desperdício enquanto horizonte supremo de moralidade de nossas ações. Há uma capacidade de controle a partir da capacidade de prever resultados e grandeza que funda o trabalho como modo de apropriação de minha força e dos objetos. Este controle é encarnado no primado da utilidade.

Mas se nos perguntarmos sobre o que devemos entender por "utilidade" neste contexto, teremos que apelar para um texto do início dos anos 30, intitulado "A noção de dispêndio". Nele, lemos:

A utilidade tem teoricamente como finalidade o prazer - mas somente sob uma forma moderada, pois o prazer violento é tido como patológico - e se deixa limitar, por um lado, à aquisição (praticamente à produção) e à conservação dos bens e, por outro, à reprodução e à conservação das vidas humanas [...] No conjunto, qualquer julgamento geral sobre a atividade social subentende o princípio de que todo esforço particular deve ser redutível, para ser válido, às necessidades fundamentais da produção e da conservação ${ }^{4}$.

Ou seja, fica claro como a utilidade aparece não apenas enquanto modo de descrição da racionalidade própria a um sistema sócio-econômico determinado, mas principalmente como o princípio fundamental de definição moral da natureza dos sujeitos próprios a tal sistema. Os sujeitos racionais no interior do capitalismo são aqueles que organizam suas ações tendo em vista sua autoconservação, a conservação de seus bens, o cálculo econômico de seus esforços e a fruição de formas moderadas de prazer, ou seja, formas de prazer que não nos coloquem fora de nosso próprio domínio. Eles são aqueles que se julgam racionais por sempre submeterem sua afetividade à reflexão sobre a utilidade e pela medida de suas ações, não apenas suas ações no interior do mundo do trabalho, mas também suas ações relativas a outros sujeitos. Dessa forma, como dirá Marx acerca do problema do fetichismo da mercadoria, as relações entre pessoas acabarão por ganhar a forma, por se submeterem à racionalidade instrumental da relações entre coisas: "a humanidade, no tempo humano, antianimal do trabalho é em nós o que nos reduz a coisas"5. Tempo antianimal porque tempo que se acumula, que conta,

4 BATAILLE, Georges. A parte maldita, precedida de "A noção de dispêndio", p. 20.

5 Idem; O erotismo, p. 184. Neste sentido, marxistas como Moishe Postone acabam por se aproximar, mesmo a contragosto, de tal tipo de crítica do trabalho colocada em circulação por Bataille quando insistem que "o trabalho social não é somente o objeto da exploração 
que se dispõe como unidade bruta de contagem, tempo disciplinar do cálculo dos meios em relação a fins. Desta forma: "o tempo perde o seu caráter qualitativo, mutável e fluido: ele se fixa num continuum delimitado com precisão, quantitativamente mensurável, pleno de 'coisas' quantitativamente mensuráveis" 6 .

Estas questões são importantes por nos lembrar que a dominação no trabalho não está ligada apenas à impossibilidade dos produtores imediatos disporem de sua própria produção e dos produtos por eles gerados. Não se trata apenas de uma questão de apropriação e dominação consciente, através da "cooperação histórico-universal dos indivíduos"; apropriação destes "poderes que, nascidos da ação de alguns homens sobre os outros, até agora se impunham sobre eles, e os dominavam na condição de potências absolutamente estranhas"7. Pois, se não nos perguntarmos sobre a extensão real de tal domínio, correremos o risco de deixar dois problemas intocados, a saber, o fato da produção do valor - como forma de riqueza e de determinação de objetos - permanecer no centro das estruturas de dominação abstrata ${ }^{8}$ e, principalmente, o fato da relação sujeito/objeto continuar a ser pensada sob a forma do próprio (como expressão da consciência, seja ela falsa ou histórico-universal) e da propriedade (seja ela individual ou comunal, injusta ou justamente distribuída). O problema relativo à reflexão do trabalho acaba por definir-se como um problema de "redistribuição de propriedade", redistribuição do que se dispõe diante de mim como aquilo que tem, na sua identidade para comigo, sua verdadeira essência. Neste sentido, é difícil não aceitar que "o sujeito histórico seria nesse caso uma versão coletiva do sujeito burguês, constituindo-se e constituindo o mundo por meio do "trabalho'"9. Por isto, ao menos dentro de tal perspectiva, não faria sentido falar do trabalho como categoria de contraposição ao capitalismo, já que ele estaria organicamente vinculado às estruturas disciplinares de formação da natureza utilitária das relações próprias à individualidade liberal e seus direitos de propriedade, expressando apenas amplos processos de reificação.

Insistamos neste ponto. As discussões acerca do trabalho e sua alienação raramente estiveram dissociadas da estrutura de determinação da relação sujeito/objeto sob a forma da propriedade. Mesmo quando

e dominação, mas é, ele próprio, o terreno da dominação. A forma não pessoal, abstrata, 'objetiva' de dominação característica do capitalismo está aparentemente relacionada à dominação dos indivíduos por seu trabalho social" (POSTONE, Moishe. Tempo, trabalho e dominação social, São Paulo: Boitempo, 2014, p. 150).

6 LUKÁCS, György. História e consciência de classe, op. cit., p. 205.

7 MARX, Karl. A ideologia alemã, Rio de Janeiro: Civilização Brasileira, 2007. p. 61.

8 Cf. POSTONE, idem, p. 151.

9 Idem, p. 99. 
elas estiveram ligadas às exigências de apropriação da produção e seus produtos pelos produtores imediatos, ela se limitava a uma discussão sobre os destinos da propriedade ${ }^{10}$. Para além da inegável importância política do problema da espoliação, há uma discussão sobre a estrutura dos processos de reconhecimento no interior do trabalho que se faz urgente. Normalmente, pensamos o trabalho como a produção do que me é próprio, do que é a confirmação especular de minhas próprias determinações, mesmo que tal próprio não seja o indivíduo isolado, mas o "ser social", a "consciência de classe"11. Neste sentido, passar do indivíduo ao ser social, à consciência de classe não implica, necessariamente, uma mudança ontológica se a crítica ao trabalho na sociedade capitalista limitar-se à critica à destinação da propriedade ou à sua forma de manifestação. Pois, sendo propriedade privada ou coletiva, cooperação de indivíduos livres ou sujeição de trabalhadores assalariados, não se muda o fator fundamental: minha atividade deve produzir o que me confirma no interior da esfera do próprio. Ela me assegura no espaço do familiar. Assim, proletário ou capitalista, são os afetos do sujeito burguês e suas exigências de identidade que continuam a nos guiar e a guiar, inclusive, os móbiles da crítica $^{12}$. Como o burguês que dispõe, no interior de sua home, os objetos que contam são seus feitos pessoais, suas pequenas idiossincrasias, viagens exóticas e lembranças; a consciência que trabalha parece querer transformar a natureza à sua volta em uma grande home decorada por objetos que são a expressão de sua própria história. Ela quer o afeto da segurança do reencontro, pois a propriedade é, no fundo, um afeto; um

10 No fundo, vale neste caso a afirmação precisa de Esposito: "Que se deva apropriar-se do nosso comum (através do comunismo e do comunitarismo) ou comunicar o nosso próprio (através da ética comunicativa), o resultado não muda: a comunidade continua duplamente vinculada à semântica do próprio" (ESPOSITO, Roberto. Communitas: origine e destino della comunitá, Turim: Einaudi, 1998, p. IX).

11 De nada adianta afirmar, por exemplo, "que a consciência de classe não é a consciência psicológica de cada proletário ou a consciência psicológica de massa no seu conjunto, mas o sentido, que se tornou consciente, da situação histórica de classe" (LUKÁCS, György. História e consciência de classe, op. cit., p. 179). A pergunta correta é: qual a distinção formal entre a consciência do sentido na consciência de classe e na consciência psicológica? O que é o "sentido" nestes dois casos, a não ser a apropriação reflexiva do regime de causas no interior de uma totalidade de relações representáveis, totalidade no interior da qual a representação determina a forma geral do que há a ser apreendido? Não seria prova de ingenuidade dialética deixar de começar por se questionar sobre os limites das experiências impostas pela forma da representação?

12 Daí, por exemplo, este horizonte de transparência absoluta que opera no recurso à crítica do desvelamento da totalidade em Lukács. Lembremos, neste sentido, do peso determinista de afirmações como: "Ao se relacionar a consciência com a totalidade da sociedade, tornase possível reconhecer os pensamentos e os sentimentos que os homens teriam tido numa determinada situação de sua vida, se tivessem sido capazes de compreender perfeitamente esse situação e os interesses dela decorrentes, tento em relação à ação imediata, quanto em relação à estrutura de toda a sociedade conforme esses interesses" (LUKÁCS, György. História e consciência de classe, São Paulo: Martins Fontes, 2003, p. 141). 
afeto de segurança. Assim, quando o trabalho aliena-se de seu trabalho, submetendo-o à dominação de uma força estranha, a crítica insistirá que tal estranhamento precisaria desaparecer por completo. Nada deve ser estranho ao homem que se reencontra a si mesmo no interior do trabalho. Como dizia o liberal Locke, que parece ter neste debate a palavra final, aquilo no qual trabalho é meu, é-me próprio ${ }^{13}$.

Melhor seria, no entanto, compreender como o trabalho é a produção do impróprio, como há um estranhamento que não é simplesmente alienação, mas abertura ao que não se dispõe diante de mim como aquilo que se submete a meu tempo, meu espaço, minha forma, minhas relações de causalidade. Eliminar toda forma de estranhamento, ou compreender todo estranhamento como alienação a ser superada, é transformar o trabalho em forma maior de domínio de um mundo no qual tudo se transforma à semelhança da consciência. Neste caso, é melhor começar por meditar o porquê de alguém como Adorno afirmava que a identidade era a forma originária da ideologia. Por mais paradoxal que isto possa parecer, superar o trabalho alienado é indissociável da capacidade de permitir que o estranhamento circule como afeto do mundo do trabalho. Estranhamento não como Entfremdung (uma péssima escolha de tradução, dessas que é difícil perdoar), mas como unheimlichkeit. Há uma espoliação no mundo do trabalho que não é apenas a espoliação econômica do mais-valor, mas é espoliação psíquica do afeto de estranhamento. $\mathrm{O}$ mesmo afeto que define a possibilidade de relação do sujeito a si para além das ilusões de transparência reconquistada pela consciência.

\section{A gênese psicológica da disciplina do trabalho}

Tentemos fundamentar melhor tais estratégias de discussão começando por compreender de forma mais sistemática a gênese psicológica das estruturas disciplinares próprias ao trabalho. Isto no permitirá, mais a frente, definir a configuração tradicional de tais estruturas, assim como suas mutações contemporâneas. Lembremos como, nas sociedades capitalistas, o trabalho foi pensado como uma das versões mais bem acabadas de certo processo moral de formação

13 Lembremos do sentido desta afirmação canônica de Locke: "Da mesma forma que a Terra e todas criaturas inferiores são comuns a todos os homens, cada homem tem a propriedade em sua própria pessoa. A este respeito, ninguém tem direito algum a não ser ele mesmo. $\mathrm{O}$ trabalho (labour) de seu corpo e a obra (work) de suas mãos, pode-se dizer, são propriamente dele. Qualquer coisa que ele remova do estado que a natureza a proveu e deixou, ele misturou nela seu trabalho e a ela acrescentou algo que é ele próprio, e por isto faz dela sua propriedade" (LOCKE, John. Two treatises of government, Cambridge University Press, 1988, p. 288). 
em direção ao autogoverno. Através do trabalho, aprendemos a impor uma lei à vontade, lei que deve ser reconhecida por mim como expressão de meu ser mais próprio. Esta vontade que submete outras vontades e que aparece assim para o sujeito como um dever que ele mesmo põe para si, dever que lhe permite relativizar as exigências imediatas de autossatisfação, é um fator decisivo na constituição da noção moderna de autonomia. Por isto, só aqueles capazes de trabalhar são autônomos; não apenas no sentido material de serem capazes de prover seus próprios sustentos, mas no sentido moral de serem capazes de impor para si mesmo uma lei de conduta que é a expressão de sua própria vontade ${ }^{14}$. Há uma profunda relação entre trabalho e formação moral já há muito explorada. E se lembramos da ideia de Rousseau (2000), para quem a verdadeira liberdade é a capacidade de dar para si mesmo sua própria lei, ser legislador de si mesmo, então seremos obrigados a dizer que a possibilidade do trabalho é exercício mais importante para a efetivação do conceito moderno de liberdade.

No entanto, é evidente a natureza profundamente disciplinar desta modalidade de autogoverno que é o trabalho. Trabalhar implica submeter a vontade a uma hierarquia de prioridades, submeter o tempo a um padrão de cálculo, ocupar o espaço de certa forma, limitar a atenção, adiar certas exigências de satisfação. Mas só posso suportar tal submissão porque compreendo o trabalho como a resposta a um "chamado" que me dá forças para perseverar na vontade, para abrir mão do gozo imediato e controlar meus desejos. Tal chamado me ensina que, quando a carne fala mais alto, devo, "tomar banhos frios e trabalhar na minha vocação" de maneira compulsiva. Neste sentido, trabalhamos não apenas para sermos reconhecidos enquanto sujeitos dotados de certas habilidades importantes para a vida social. Trabalhamos para sermos reconhecidos por um Outro que habita nossas fantasias, que nos observa como se estivéssemos em um panopticon privado que nos "chama" para assumir um tipo de relação aos desejos e à vontade que fundam a idealidade de nossa própria personalidade. A servidão real é substituída pela internalização de uma representação imaginária de autoridade fantasmaticamente constituída e responsável pela organização da identidade psicológica a partir de uma "vocação", fundamento libidinal para a definição da coerência da personalidade e da unidade de conduta. A pressão da internalização das disposições disciplinares que me permitem trabalhar e evitar a dispersão da vontade sustenta-se, em larga

14 Para uma discussão a respeito da natureza disciplinar da autonomia, remeto a SAFATLE, Vladimir, O dever e seus impasses, São Paulo: Martins Fontes, 2013. 
medida, na crença de que tais disposições são elementos fundamentais para a formação subjetiva de uma identidade psicológica desejada. Isto pode nos explicar porque, ainda hoje, é possível traçar, por exemplo, sólidas correlações entre longos períodos de desemprego e transtornos no sentimento de autoidentidade capazes de, no limite, levar à experiência de "morte social". ${ }^{15}$

Esta correlação entre trabalho e processo de formação da identidade é a base do clássico estudo de Max Weber, A ética protestante e o espírito do capitalismo. Nele, Weber procurou mostrar como a modalidade hegemônica de trabalho exigida pelo processo de desenvolvimento do capitalismo assentava-se na constituição de noções de individualidade e identidade psicológica cuja principal característica era um conceito de autonomia tributária à internalização do poder pastoral próprio à teologia protestante.

Relembremos alguns aspectos fundamentais da hipótese weberiana. Ao insistir que a racionalidade econômica dependia fundamentalmente da disposição dos sujeitos em adotar certos tipos de conduta, Weber lembrava que nunca haveria capitalismo sem a internalização psíquica de uma ética protestante do trabalho e da convicção, estranha ao cálculo utilitarista e cuja gênese deve ser procurada no calvinismo. Tal ética, Weber encontrou no ethos protestante da acumulação de capital e do afastamento de todo gozo espontâneo da vida. Pois o trabalho que marcava o capitalismo como sociedade de produção era um trabalho que não visava exatamente o gozo do serviço dos bens, mas a acumulação obsessiva daqueles que, mesmo produzindo valor "não retiram nada de sua riqueza para si mesmo, a não ser a sensação irracional de haver 'cumprido' devidamente a sua tarefa" (WEBER, 2001, p. 56). Weber chega a falar em uma "sanção psicológica" (p. 102) produzida pela pressão ética e satisfeita através da realização de um trabalho como fim em si, ascético e marcado pela renúncia ao gozo. Um trabalho no interior do qual a profissão aparece como dever que se cumpre, como resposta que se dá a um "chamado" tão claramente presente na própria ideia de "vocação". ${ }^{16}$

No entanto, devemos lembrar aqui como Freud, à sua maneira, foi aquele que forneceu o aparato conceitual para compreendermos tal concepção de trabalho fundamental para o desenvolvimento do capitalismo como matriz de sofrimento psíquico. Freud raramente discute

15 Ver, por exemplo, o estudo de Kasl, Rodrigues e Lasch, 1999. Para um caso brasileiro, ver Tolfo et al. 2004.

${ }_{16}$ O que explica o aparecimento da "valorização do cumprimento do dever no seio das profissões mundanas como o mais excelso conteúdo que a autorrealização moral é capaz de assumir" (WEBER, 2001, p. 72). 
diretamente problemas ligados ao mundo do trabalho ${ }^{17}$. No entanto, ele insiste que toda internalização de sistemas de regras, normas e leis de conduta com forte apelo moral, é feita através de dinâmicas repressivas em relação à satisfação pulsional e não há porque temer o uso desta palavra, mesmo após as críticas feitas por Foucault à chamada "hipótese repressiva" (FOUCAULT, 1978). Isto vale também para a formação da estrutura psíquica necessária para entrar no mundo do trabalho. Marx já falava da submissão ao trabalho capitalista como "repressão (Unterdrückung) de um mundo de capacidades e pulsões (Trieben) produtivas"18.

Vimos como Freud é sensível às ambivalências deste processo repressivo que constitui o superego como "instância moral de observação" de si. Para sustentar sua eficácia, tal repressão não pode ser simplesmente vivenciada como coerção. Nenhuma forma de adesão sustenta-se na simples coerção. Freud nos lembra como há sempre uma demanda de amor e reconhecimento, direcionada a um Outro fantasmático, que sustenta minha adesão muda a tais dinâmicas repressivas. Demanda de reconhecimento que se manifesta como sentimento patológico de culpa em relação a toda satisfação libidinal que leve em conta o caráter fragmentário e polimórfico das pulsões, já que se sentir culpado é uma maneira peculiar de ser reconhecido. Tal sentimento patológico de culpa é um dispositivo importante na compreensão do modo de conformação da individualidade a uma economia psíquica que encontra uma de suas fontes na internalização de disposições para um regime de trabalho descrito por Weber ao tematizar a ética protestante. Através da culpa, afasto minha atividade daquilo que Weber chamou de "gozo espontâneo da vida", aprendo a calcular minhas ações a partir de sua "utilidade" suposta, suporto as frustrações advindas das minhas exigências de satisfação pulsional e conformo meu trabalho a uma espécie de ritual obsessivo-compulsivo de autocontrole que só pode levar à formação de uma personalidade rígida e clivada; modelo de personalidade que Freud

17 Embora devemos lembrar como o inconsciente é, acima de tudo, uma modalidade de trabalho. Haja vista a maneira com que Freud fala de Traumarbeit (trabalho do sonho), Trauerarbeit (trabalho do luto), Durcharbeitung (perlaboração), Bearbeitung (elaboração). Neste sentido, há de se salientar como há um trabalho do inconsciente que nada tem a ver com o trabalho enquanto expressão das representações da consciência. Lembremos, por exemplo, do que Freud diz a respeito do trabalho do sonho: "Ele não pensa, não calcula e não julga, mas limita-se a transformar/remodelar (umzuformen)" (FREUD, Sigmund. "Die Traumdeutung", In: Gesammelte Werke - vol II/III, Frankfurt: Fischer, 1999, p. 511). Esta transformação que não é fruto do que pode ser apropriado sob a forma de cálculo, julgamento e pensamento representacional, mas que é plasticidade contínua sob a pulsação do que nunca coloca-se sob a forma da consciência é figura privilegiada do trabalho livre.

18 MARX, Karl. O Capital - vol. I, São Paulo: Boitempo, 2013, p. 406. 
descreve de forma precisa ao cunhar a categoria patológica de neurose obsessiva ${ }^{19}$.

Na verdade, podemos, através de Freud, defender que a autonomia produzida por este modelo de atividade laboral era indissociável de um bloqueio nas expectativas expressivas do trabalho manifestas tão claramente nas modalidades singulares do trabalho do inconsciente. A possibilidade de expressão de si é bloqueada não apenas porque o trabalhador está submetido a uma divisão social no interior da qual ele realiza o que não planeja, no interior da qual sua vontade está submetida à vontade de um outro. A expressão de si está bloqueada porque sua atividade está submetida a princípios psicológicos que perpetuam uma personalidade clivada, rígida, fortemente determinada e atormentada pelo controle das pulsões.

Tal personalidade, marcada pela rigidez e pela estereotipia, forneceu a correlação psíquica necessária para um mundo do trabalho dominado por empresas e organizações que teóricos da administração descreveram como submetidas a uma concepção mecanicista (MORGAN, 1995). Trata-se de um modelo organizacional que imperou na primeira metade do século XX e que alcançou seu apogeu através das teorias tayloristas e fordistas, com suas técnicas de tempo, movimento e adestramento corporal. Nesta concepção, na qual as organizações aparecem preferencialmente sob a metáfora da máquina, o trabalho é submetido à "burocratização e rotinização da vida em geral" (p. 25). Tal trabalho exige uma individualidade que se vincule afetivamente à representação estática de funções ligadas à vocação profissional, assim como à divisão estrita entre planejamento e realização do trabalho. O sentimento de reificação produzido por tal dinâmica do trabalho é compensado pelos chamados

19 Ao criar a neurose obsessiva, Freud procurava especificar um tipo de neurose cujo mecanismo de defesa privilegiado não era a conversão somática histérica, mas o deslocamento de afeto em direção a outras representações. Assim, "a representação enfraquecida permanece na consciência apartada de todas as associações, mas seu afeto, agora livre, se liga a outras representações, nelas mesmas não irreconciliáveis, e que, através desta "falsa conexão", se transformam em representações obsessivas" (FREUD, Sigmund. As psiconeuroses de defesa). Normalmente, tratava-se de uma representação de cunho sexual irreconciliável com as exigências morais da consciência. Esta diferenciação funcional da neurose obsessiva ganhará complexidade com o desenvolvimento da hipótese freudiana do Complexo de Édipo e de seu modelo de socialização de conflitos. A ideia de um afeto que se transforma em representação obsessiva, como um corpo intruso que insiste por todos os lados na consciência, será a base para um sofrimento marcado pela transformação patológica dos modos de internalização de princípios de autocontrole, de responsabilidade, de domínio das expressões e emoções, assim como da coerência dos comportamentos resultantes das identificações produzidas no interior do núcleo familiar. Neste sentido, os mecanismos de individualização dos sujeitos modernos, responsáveis por um processo de constituição de si através das dinâmicas de identificação e internalização de princípios de autocontrole e de unidade subjetiva, acabam por se transformar na matriz mesma de sofrimento psíquico. 
à famosa "sensação irracional de ter cumprido com seu dever". Não foi por acaso que boa parte das primeiras críticas ao modelo taylorista e fordista de gestão veio de psicólogos sociais influenciados pelas teorias freudiana ${ }^{20}$. Eles eram sensíveis ao preço psicológico que tal noção de trabalho exigia.

Seria equivocado defender que tal modelo de trabalho, com suas matrizes de sofrimento psíquico, não faz mais parte de nosso presente. Mas é certo que ele convive atualmente com formas distintas de dominação psíquica no universo do trabalho, configuradas a partir de uma racionalidade outra. Tais novas formas são hegemônicas não necessariamente por darem conta de um maior número de casos, mas por constituírem a matriz ideológica dos discursos contemporâneos de justificação do universo do trabalho nas sociedades capitalistas avançadas.

\section{Marx, os animais e os humanos}

Mas para melhor compreender tal mutação na estrutura disciplinar do trabalho, faz-se necessário uma espécie de parênteses. Voltemos à filosofia social e perguntemos sobre o porquê então que uma certa tradição dialética viu, no trabalho, algo mais do que a reiteração de tais processos disciplinares que nos levariam, necessariamente, a modelos cada vez mais evidentes de reificação social e de sofrimento psíquico. Por que tal tradição insistiu, para além da estrutura disciplinar da autonomia, em lembrar que o trabalho deveria também ser compreendido como modelo fundamental de expressão subjetiva no interior de realidades sociais intersubjetivamente partilhadas, isto a ponto de elevá-lo juntamente com o desejo e a linguagem - à condição de um dos eixos de constituição daquilo que podemos entender por "forma de vida"? Tal aposta no trabalho como processo emancipatório de reconhecimento era, de fato, possível e necessária ou não passava da expressão dos equívocos de filosofias tão fascinadas pelas dinâmicas de transformação que tendiam a negligenciar como atividades socialmente avalizadas? Funcionaria o trabalho fundamentalmente como processo de reiteração de sujeições?

Partamos, para isto, da definição do trabalho como modelo de exteriorização (Entäusserung) do sujeito sob a forma de um objeto.

20 Lembremos, por exemplo, de Elton Mayo e de seus famosos experimentos de Hawthorne (1924-1927): "Em lugar da linguagem moral vitoriana do 'caráter', Mayo, que fizera sua formação como psicanalista junguiano, introduziu a imaginação psicanalítica no local de trabalho. A intervenção de Mayo na empresa teve um caráter rigorosamente terapêutico" (ILLOUZ, 2011, p. 23). 
Lembremos, a este respeito, da famosa comparação de Karl Marx, certamente um dos pensadores modernos que melhor configurou certa via ainda hegemônica na caracterização do trabalho:

Uma aranha executa operações que se assemelham às do tecelão e uma abelha envergonha, através da construção de sua colmeia, vários construtores humanos. Mas o que distingue o pior construtor da melhor abelha é que ele construiu os favos na cabeça antes de construi-los na cera. No final do processo de trabalho, vemos um resultado que desde o início estava na representação do trabalhador, presente como ideal (ideell). Ele não efetua apenas uma modificação formal no que é natural, mas nele realiza também seu próprio objetivo, que ele conhece, que determina como uma lei a modalidade de sua ação e ao qual ele deve subordinar (unterordner) sua vontade ${ }^{21}$.

Como lembra Habermas, através de afirmações como esta Marx eleva o trabalho não apenas a uma categoria antropológica fundamental, mas a uma categoria da teoria do conhecimento, já que a compreensão dos objetos como objetos trabalhados permite o desvelamento da natureza histórico-social das estruturas normativas da experiência. Marx partilha com Hegel a noção de que a modalidade de síntese responsável pela constituição dos objetos da experiência não seria produção de uma subjetividade transcendental, mas de uma subjetividade empírica às voltas com os modos de reprodução material da vida ${ }^{22}$. Tal ampliação da função da categoria de trabalho é paga, entre outras coisas, com a necessidade de uma distinção ontológica entre expressão subjetiva e comportamento natural. Habermas (1976, p. 64) sintetiza bem tal distinção ao afirmar que "Marx não apreende a natureza sob a categoria de um outro sujeito, mas apreende o sujeito sob a categoria de uma outra natureza". Já a definição de Marx de que "toda produção é apropriação (Aneignung) da natureza pelo indivíduo no interior de e mediada por uma determinada forma de sociedade" 23 , é clara em suas distinções ontológicas. Apropriar-se é relacionar-se com o que não me é próprio e, por mais que formas sociais definam modalidades historicamente determinadas de apropriação com suas consequências específicas, há de se insistir novamente que a dinâmica da apropriação pressupõe um modo estrutural de pensar a ação de produção como dispor do que não me é próprio, como absorção do que se coloca como inicialmente estranho, redução do estranho ao familiar, que já traz consequências decisivas para a orientação normativa da crítica social.

${ }^{21}$ MARX, Karl. Das Kapital I, Berlin: Dietz Verlag, 1983, p. 130.

22 Ver, a este respeito, Habermas, 1976, p. 60.

${ }^{23}$ MARX, Karl. Grundrisse, São Paulo: Boitempo, 2011, p. 43. 
Marx descreve em vários momentos tal apropriação como um "metabolismo" (Stoffwechsel) ${ }^{24}$ através do qual "a totalidade da natureza é socialmente mediada e, inversamente, a sociedade é mediada através da natureza pensada como componente da realidade total" 25 . Neste metabolismo, as modificações ocorrem a partir da passagem da potência ao ato, na qual o trabalhador "desenvolve as potências que na natureza jazem latentes" ${ }^{26}$, convertendo "valores de uso apenas possíveis (mögliche)" em valores de uso reais (wirkliche). Tal processo compreendido como a passagem do possível ao real é o que deve ser melhor compreendido. Como vimos, Marx parece inicialmente dizer que o trabalho distingue-se de toda outra atividade por ser exteriorização de uma idealidade, mas há de se definir melhor o que devemos entender por "ideal" neste contexto. Pois, se "ideal" significar simplesmente a transformação da natureza a partir de uma ação dirigida por uma finalidade previamente determinada, como o texto de Marx parece inicialmente nos fazer acreditar, sua conformação a uma forma previamente presente como representação ideal, então será difícil não perceber nesta atividade algo que dificilmente pode ser chamado de "processo". A passagem do possível ao real operada pelo trabalho social não passaria de mera exteriorização de uma finalidade abstrata.

Se este fosse o caso, tal modo de determinação do trabalho nos impediria, em última instância, de distingui-lo do comportamento natural. Todo organismo biológico tem a capacidade de se orientar e operar escolhas a partir de uma finalidade que serve, neste contexto, de norma de avaliação. O filósofo da biologia Georges Canguilhem é preciso neste sentido: sendo a vida uma "atividade de oposição à inércia e à indiferença" (CANGUILHEM, 1983, p. 208), toda individualidade biológica diferencia-se e escolhe a partir de normas. Neste sentido, toda individualidade biológica age a partir de um "ideal" com forte potencial normativo, valorativo e, não devemos esquecer, transformador do meioambiente.

Se quisermos dar alguma realidade à dicotomia afirmada por Marx, talvez devamos voltar a uma importante afirmação presente nos Manuscritos (2004, p. 84): "O animal é imediatamente um com a sua atividade vital. Não se distingue dela, é ela. O homem faz da sua atividade vital mesma um objeto da sua vontade e da sua consciência. Ele tem atividade vital consciente. Esta não é uma determinidade (Bestimmtheit)

\footnotetext{
24 Por exemplo: "o processo de trabalho é inicialmente um processo entre o homem e a natureza, um processo no qual, através de sua própria ação, ele media, regula e controla seu metabolismo com a natureza" (MARX, Karl. Das Kapital I, op. cit., p. 129).

25 SCHMIDT, Alfred. The concept of nature in Marx, Londres: Verso, 2014, p. 79.

26 MARX, idem, p. 129.
} 
com a qual ele coincide imediatamente". A diferença entre a transformação do meio-ambiente, devido ao comportamento animal, e o trabalho humano está no fato da relação de identidade imediata pressuposta pela animalidade, isto ao menos segundo Marx, perder-se a partir do momento em que o homem "faz de sua atividade vital um objeto de sua vontade e consciência". Pois, desta forma, o homem, segundo o jovem Marx, poderia produzir mesmo livre das determinações próprias à necessidade natural ${ }^{27}$. Sua atividade: "não é uma determinidade com a qual ele coincide imediatamente".

Assim, se o trabalho é um modelo de expressão subjetiva, não há como pensá-lo como passagem simples da interioridade pensada à exterioridade constituída. Ele é expressão do estranhamento da vontade às formas que se colocam como "representações naturais", no sentido que Hegel utiliza tal termo na Fenomenologia do Espírito ${ }^{28}$. Isto talvez explique porque Marx seja obrigado a definir a ideia trabalhada como uma lei que "subordina" a vontade. Quem diz "subordinação" diz imposição de uma norma a algo que lhe seria naturalmente refratário. A vontade humana precisa ser subordinada à ideia trabalhada porque ela pode, a todo momento, subvertê-la, desertá-la. Há uma característica negativa da vontade presente na capacidade que tenho de flertar com a indeterminação através do que Hegel chamou um dia de trabalho do negativo ${ }^{29}$. Já a abelha de Marx não precisa subordinar sua vontade à lei que determina sua ação porque ela não tem outra vontade possível, sua vontade está completamente adequada à lei, sua potência é imediatamente ato. Por isto, podemos dizer que a existência mesma do trabalho pressupõe a possibilidade humana, possibilidade esta que é exclusivamente humana, do não-exercício do que se coloca como potência. De uma certa forma,

27 Daí uma afirmação como: "o animal produz apenas sob o domínio da necessidade física imediata, enquanto o homem produz mesmo livre da necessidade física, e só produz, primeira e verdadeiramente em liberdade para com ela; o animal só reproduz a si mesmo, enquanto homem reproduz toda a natureza" (MARX, Karl. Manuscritos econômico-filosóficos, op. cit., p. 85 [trad. modificada]).

28 Cf. HEGEL, G. W. F. Fenomenologia do Espírito.

29 Sobre a natureza negativa da vontade, ver Safatle, 2012. Nesta ocasião, tentei mostrar como aqueles que compreendem o trabalho dialético do negativo como expressão de carência, resignação moral (esta é a pior das leituras) ou mera privação leem mal a dialética hegeliana. Melhor seria se eles compreendessem a negatividade como uma atividade de posição do excesso dos possíveis em relação à limitação atual do real, uma pressão da infinitude em direção não à totalidade efetivamente posta em um horizonte de "suspensão do tempo", mas em direção à posição da processualidade do real, com sua dialética contínua de determinação e indeterminação que permite a abertura à dinâmica processual das formas. A atividade como negatividade é a única operação capaz de sustentar a recuperação de uma imanência que não se deixa confundir com as ilusões do imediato e seus riscos de estaticidade. Dentro de uma perspectiva realmente dialética, a falta nunca é expressão da essência desejo, mas expressão da limitação do campo atual de determinações. Mas, bem, um dia você descobre que há certas coisas que precisará repetir o resto da vida. 
a expressão que se manifesta no interior do trabalho será sempre marcada por esta potência de não passar imediatamente ao ato ou por esta potência de alterar a determinidade que me seria imediatamente adequada ${ }^{30}$. Maneiras de expressar como a atividade humana encontra sua essência no excesso dos possíveis (que podem aparecer inicialmente como impossívei ${ }^{31}$ ) em relação aos limites das determinidades postas.

Neste sentido, podemos insistir em uma certa matriz hegeliana deste modo de pensar a dimensão ontológica do trabalho. Como já foi dito, vêm de Hegel as primeiras colocações sobre o trabalho como fonte de reconhecimento social. No entanto, é interessante lembrar como, em vários de seus textos, o trabalho aparece não como a simples exteriorização de uma ideia, mas como modo de defesa contra a angústia. A consciência se angustia diante da possibilidade de não ter objetividade alguma, de não ter forma alguma que seja reconhecida socialmente; por isto, ela trabalha. $\mathrm{Na}$ verdade, ela trabalha como quem se defende contra uma possibilidade de indeterminação que está sempre a lhe assombrar. No entanto, os objetos trabalhados sempre terão as marcas desta sombra. Segundo Hegel (1992, p. 132), "a relação negativa para com o objeto torna-se a forma do mesmo e algo permanente". Ou seja, a impossibilidade do ser humano encontrar um objeto que lhe seja natural, algo que seja a expressão natural de sua vontade, ganha a forma de um objeto trabalhado, pois faz parte de toda defesa absorver algo do medo contra o qual ela foi erigida.

Neste sentido, podemos a partir disto tentar complexificar nossa noção de trabalho alienado. Normalmente, entendemos por trabalho alienado aquela modalidade de atividade laboral na qual não me reconheço no que produzo, já que as decisões que direcionam a forma da produção foram tomadas por um outro. Desta forma, trabalho como um outro, como

30 Impossível não ler de maneira dialética a compreensão precisa de Agamben a respeito desta dinâmica entre potência e ato: "Se uma potência de não ser pertence originalmente a toda potência, será verdadeiramente potente só quem, no momento da passagem ao ato, não anular simplesmente sua potência de não, nem deixá-la para trás em relação ao ato, mas a fizer passar integralmente no ato como tal, isto é, poderá não-não passar ao ato", pois "a passagem ao ato não anula nem esgota a potência, mas esta se conserva no ato como tal e, particularmente em sua forma eminente de potência de não (ser ou fazer)" (AGAMBEM, Giorgio. A potência do pensamento: ensaios e conferências, Belo Horizonte: Autêntica, 2015, p. 253).

31 Como procurei insistir a respeito da função dos "impossíveis" em Lacan como possíveis impossíveis a partir dos limites da situação atual (Ver SAFATLE, 2006). Outro que compreendeu claramente a função de latência própria aos impossíveis, mas que certamente não estaria de acordo com as conclusões que desdobro é FAUSTO, Ruy, Marx: lógica e política - tomo II: investigações para uma reconstituição do sentido da dialética, São Paulo: Brasiliense, 1987, p. 188-201. 
se estivesse animado pelo desejo de um outro. Como dirá o jovem Marx (2004, p. 83),

Assim como na religião a autoatividade da fantasia humana, do cérebro e do coração humanos, atua independentemente do indivíduo e sobre ele; isto é como uma atividade estranha, divina ou diabólica, assim também a atividade do trabalhador não é sua autoatividade. Ela pertence a outro, é a perda de si mesmo.

Superar tal perda do que me é próprio seria indissociável da capacidade de constituir-me como sujeito capaz de apropriar-me da totalidade das relações produtoras de sentido social com suas mediações, colocandome assim como a "essência das forças motrizes" 32. Constituição ligada, segundo certa tradição marxista, à formação da consciência de classe proletária, única capaz de realizar a apreensão do "caminho do processo de desenvolvimento histórico como totalidade" 33 .

Mas podemos também insistir que não é certo que tal modalidade de apropriação da totalidade possa nos levar à superação da alienação. Tal apropriação normalmente determina a totalidade como uma estrutura fechada na qual todas as relações são necessárias, pois são previamente determinadas no interior de um sistema metaestável que encontra em um conceito de história teleologicamente orientado seu campo de desdobramento e nos modos de apreensão reflexiva da consciência seu destino final. Apropriar-se da totalidade aparece aqui como o ato de reconhecer, na dimensão de tudo o que aparece, a natureza constituinte de uma subjetividade que abandonou sua crença no encaminhamento transcendental apenas para encontrar, em operação no interior do trabalho social com suas relações de interação, a mesma forma de subsunção do diverso da sensibilidade em representações que animavam a atividade teórica.

Melhor seria lembrar como o trabalho alienado é, ao contrário, exatamente aquele no qual aceitamos uma leitura literal da ideia de Marx, segundo a qual "no final do processo de trabalho, vemos um resultado que desde o início estava na representação do trabalhador, presente como ideal". Neste caso, a imaginação do trabalhador é apenas a faculdade humana da planificação, do esquematismo prévio, um pouco como o sujeito kantiano com seu esquematismo transcendental capaz de determinar previamente a forma geral do que há de ser representado. Este trabalho já é o trabalho industrial da fábrica, que só produz objetos que são exemplares intercambiáveis da ideia. Neste trabalho, a expressão

32 LUKÁCS, György. História e consciência de classe, op. cit., p. 171.

33 Idem, p. 317. 
tem uma estrutura especular, já que o homem encontra, no objeto, apenas o ideal que ele próprio previamente projetou. Mas não é possível para um pensamento materialista aceitar que, no processo de trabalho, o resultado final já estava determinado no início como representação, pois isto implicaria aceitar que a passagem à existência, que a posição, nada acrescentaria à determinação categorial ${ }^{34}$, como se da determinação à existência não houvesse processo. Se assim o fosse, nunca poderíamos entender como, no interior do processo de trabalho, categorias são reconstruídas a partir de negações determinadas produzidas pelo "metabolismo" da atividade humana com seus objetos; não poderíamos compreender como o início, mesmo quando formalmente idêntico, é semanticamente outro.

\section{Identidades}

Se quisermos procurar outra via para encaminhar o problema da superação da alienação, talvez valha a pena lembrar de uma importante dimensão da crítica marxista à divisão social do trabalho. No primeiro livro de O Capital, Marx sublinha como o modo industrial de trabalho no capitalismo havia transformado trabalhadores em membra disjecta, como se seus corpos tivessem sido marcados pelo caráter unidimensional do trabalho industrial. "Não só os trabalhos parciais particulares são separados entre diferentes indivíduos, mas o próprio indivíduo é mutilado, transformando-se em motor automático de um trabalho parcial, realizando assim a fábula absurda de Menênio Agripa que representa um homem como simples fragmento de seu próprio corpo"35. Como já foi dito, há uma individualização pelo trabalho que se impõe através da funcionalização brutal da personalidade e da "repressão de um mundo de pulsões e capacidades produtivas", pois tal individualização é integração dos sujeitos a um "corpo social de trabalho" no qual "a cooperação dos assalariados é um mero feito do capital que os emprega simultaneamente. A interconexão de suas funções e sua unidade como corpo produtivo total reside fora deles, no capital, que os reúne e os mantém unidos" 36 . Contra tal corpo social construído a partir da limitação funcional dos sujeitos, podemos lembrar desta célebre passagem da Ideologia Alemã:

\footnotetext{
34 Para uma boa discussão a este respeito a partir da afirmação kantiana de que cem táleres reais não contém mais do que já está presente em cem táleres possíveis, ver FAUSTO, Ruy, Marx: logique et politique, op. cit.

35 MARX, Karl. Das Kapital I, op. cit., p. 294

36 Idem, O Capital - vol. I, op. cit., p. 406.
} 
$\mathrm{Na}$ sociedade comunista, onde cada indivíduo não tem para si um círculo exclusivo de atividades, mas pode desenvolver suas aptidões no ramo que melhor lhe aprouver, a sociedade encarrega de regular a produção universal, com o que ela torna possível, justamente através disso, que eu possa me dedicar hoje a isto e amanhã àquilo, que possa caçar pela parte da manhã, pescar pela parte da tarde e a noite apascentar o gado, e depois de comer, criticar, se for o caso conforme meu desejo, sem a necessidade de por isto me tornar caçador, pescador, pastor ou crítico algum dia ${ }^{37}$.

Como veremos em outro capítulo, percebe-se aqui a natureza antipredicativa do reconhecimento proposto por Marx. Não me defino como caçador, pescador, pastor ou crítico, embora possa caçar, pescar ou criticar. Não estou completamente vinculado nem ao tempo originário da caça, pesca e pastoreio, nem ao tempo de apreensão reflexiva da crítica, embora possa habitar as temporalidades distintas em uma simultaneidade temporal de várias camadas. Não limito minha ação nem ao trabalho manual, nem ao trabalho intelectual. Todas essas negações demonstram como, por não passar completamente nos predicados historicamente disponíveis, o sujeito preserva algo da dimensão negativa da essência. Eis um ponto importante: a negatividade em relação às representações naturais da atividade apresentada nesta necessidade de estabelecer distinções ontológicas entre expressão subjetiva e comportamento natural, perde também manifestação no interior da relação entre o sujeito e seus predicados. O problema não diz respeito apenas a uma configuração histórico-temporal da atividade humana, mas refere-se também a uma crítica ontológica da identidade, recurso fundamental a todo pensamento dialético, pois tal trabalho no comunismo desconheceria a dominação disciplinar da identidade.

No entanto, poderíamos complexificar o diagnóstico de época e nos perguntar sobre a diferença estrutural entre tal descrição da sociedade comunista e aquele diagnóstico a respeito, por exemplo, do desenvolvimento do capitalismo nos EUA presente nos Grundrisse:

A indiferença em relação ao trabalho determinado corresponde a uma forma de sociedade em que os indivíduos passam (übergehen) com facilidade de um trabalho a outro, e em que o tipo determinado do trabalho é para eles contingente e, por conseguinte, indiferente. Nesse caso, o trabalho deveio, não somente enquanto categoria, mas na efetividade, meio para a criação de riqueza em geral e, como determinação, deixou de estar ligado aos indivíduos em sua particularidade. Um tal estado de coisas encontra-se no mais alto grau de desenvolvimento na mais moderna forma de existência da sociedade burguesa - os Estados Unidos ${ }^{38}$.

37 MARX, Karl. A ideologia alemã, op. cit., p. 56.

38 Idem, Grundrisse, op. cit., p. 58. 
Excetuando a mais moderna forma de existência da sociedade burguesa não ser exatamente uma "sociedade encarregada de regular a produção universal", assim como excetuando o fato de o primeiro trecho dizer respeito à crítica da divisão do trabalho enquanto o segundo versa sobre o conceito de trabalho abstrato, a indiferença em relação ao trabalho determinado parece a mesma tal como descrita na futura sociedade comunista. A contingência em relação ao tipo determinado de trabalho, a flexibilidade das atividades concebidas na indiferença da abstração parece, à primeira vista, algo próximo dos comunistas que caçam, pesca, pastoreiam e fazem crítica literária, mesmo que ela seja muito mais uma construção ideológica do que uma realidade efetiva em solo norte-americano. Mas, se for o caso, então será difícil não dizer que a sociedade comunista apenas realizaria o que as sociedades burguesas mais avançadas prometem sem, no entanto, serem capazes de cumprir. Como se as promessas da sociedade burguesa fossem o fundamento normativo da crítica; fundamento que finalmente poderia ser realizado no momento em que a falsa totalidade do "corpo social de trabalho" fosse abandonada em direção à verdadeira totalidade produzida pela regulação racional da produção universal.

Mas insistamos em um ponto: o que está em questão no processo histórico pensado por Marx não é apenas a superação da divisão social do trabalho, nem a defesa de uma "regulação social da produção". Mesmo tal divisão pode mostrar-se obsoleta para o capitalismo, ao menos em suas sociedades mais avançadas, como veremos mais a frente; mesmo tal regulação pode ser feita através de fortes intervenções estatais, como no modelo da socialdemocracia escandinava em seu auge. O que está em questão é, também e principalmente, a liberação do trabalho em relação à produção do valor, em relação à produção de objetos que sejam apenas o suporte próprio de determinações do valor e em relação à submissão do tempo ao tempo de produção do valor ${ }^{39}$. Não somente o vínculo à identidade social produzida pelo trabalho deve absorver uma certa potência da indeterminação, mas também o objeto produzido, a ação realizada ${ }^{40}$.

39 Lembremos de uma boa síntese feita por Postone: "O objetivo da produção no capitalismo não são os bens materiais produzidos nem os efeitos reflexivos da atividade do trabalho sobre o produtor, é o valor ou, mais precisamente, o mais-valor. Mas, valor é um objetivo puramente quantitativo, não existe diferença qualitativa entre o valor do trigo e das armas. Valor é puramente quantitativo porque, como forma de riqueza, ele é um meio objetivado: ele é a objetivação do trabalho abstrato - do trabalho como meio objetivo de aquisição de bens que não produziu" (POSTONE, Moishe, idem, p. 210).

40 A respeito deste trecho de Marx, Fausto dirá: "a mobilidade do trabalhador não realiza o universal que é ao mesmo tempo singular, o universal não é outra coisa aqui que uma sucessão de singularidades ou de particularidades" (FAUSTO, Ruy. Marx: logique et politique, Paris: Publisud, 1986, p. 114). De fato, mas poderíamos ainda nos perguntar sobre que tipo de 
Neste ponto, podemos compreender melhor a importância de sublinhar que o elemento decisivo na produção do valor é a submissão do objeto à condição do próprio. Sua intercambialidade absoluta, resultante de um modo de determinação que privilegia a instrumentalidade do mensurável, do quantificável e do calculável é a afirmação maior de que as coisas agora submetem-se por completo à condição do "próprio". Elas são a expressão do que os indivíduos podem determinar como sua propriedade, prontas a serem comparadas e avaliadas com outras propriedades, prontas para circularem em um circuito de velocidades sem fricções, dominadas na familiaridade do que conhece o tamanho e o limite, representadas sob a forma juridicamente determinada do que pode ser descrito no interior de um contrato. Mas o trabalho livre só pode ser a produção do impróprio. Um impróprio que não é propriedade comunal, mas circulação do que não tem relações especulares com o sujeito, por isto o trabalho nunca poderia ser apropriação da natureza, dominação das coisas pelas pessoas; ele é expressão do que circula fora da utilidade suposta pela pessoa.

\section{Gattungsleben}

É neste contexto que uma intuição fundamental do jovem Marx pode ser recuperada, a saber, esta, tão presente no idealismo alemão, que consiste em pensar a expressão subjetiva na dimensão do trabalho a partir do paradigma da produção estética, como se a produção estética pudesse fornecer o horizonte normativo de toda e qualquer atividade não alienada. ${ }^{41}$ Lembremos, neste sentido, da seguinte afirmação: "O animal forma (formiert) apenas segundo a medida e necessidade da espécie a qual ele pertence, enquanto o homem sabe produzir segundo a medida de qualquer espécie, e sabe considerar, por toda a parte, a medida inerente ao objeto; o homem também forma, por isso, segundo as leis da beleza" 42 .

determinação uma universalidade que é ao mesmo tempo singular deve ter. Em que condições a universalidade é posta no campo das singularidades? Insistiria que a universalidade que se singulariza implica, neste caso, recusa a determinar o singular como uma determinação completa, sendo que a incompletude de sua determinação é forma de indicar a integração do indeterminado enquanto seu momento próprio. Neste sentido, é verdade que tal determinação só é incompleta para o entendimento, mas seu gênero de posição nada tem a ver com as determinações já determinadas como possíveis. Tentarei indicar o desdobramento deste tempo através de certa leitura do que podemos entender por "vida do gênero" em Marx.

41 Esta temática encontra uma de suas principais fontes em Schiller, A educação estética do homem, São Paulo: Iluminuras, 2002. Ela pode ser encontrada no jovem Marx e em vários autores da tradição marxista, como Herbert Marcuse (ver, por exemplo, o capítulo "A dimensão estética" em MARCUSE, 1999, p. 156-174). Habermas (2000, p. 112) sintetizou bem tal temática ao afirmar que: "a produtividade do gênio artístico é o protótipo para uma atividade em que autonomia e autorrealização se unificam de tal modo que a objetivação das forças humanas essenciais perde o caráter coercitivo em face da natureza tanto externa como interna".

42 MARX, Karl. Manuscritos econômico-filosóficos, op. cit., p. 85 [trad. modificada]. 
Esta caracterização do homem como "ser sem espécie definida", "ser sem medida adequada", de onde se segue sua possibilidade de produzir segundo a medida de qualquer espécie, abre a possibilidade para uma indiferença genérica em relação à determinação própria a toda espécie nas suas relações de transformação do meio-ambiente, o que lhe leva a encontrar a medida inerente ao próprio objeto ${ }^{43}$. Liberado da condição de ser apenas objeto para-um-outro, o objeto pode ser expressão daquilo que, no sujeito, não se reduz à condição de ser para-um-outro. Daí porque encontrar a medida inerente ao objeto é, ao mesmo tempo, superar a alienação do sujeito. E o que, no sujeito, não se reduz à tal condição de ser para-um-outro, é o que nele não se configura sob a forma de espécie alguma, isto é, não tem imagem de espécie alguma pois é sua "vida do gênero" (Gattungsleben) que se objetifica no objeto trabalhado ${ }^{44}$.

No entanto, diferente do que encontramos em Aristóteles, o gênero do qual o homem faz parte é desprovido de toda e qualquer archai. Por isto, ele não pode constituir uma "natureza humana" como sistema de normas a definir a orientação da práxis. Um gênero desprovido de archai, sem origem nem destino. Mas, e há de se salientar isto com toda força, esta monstruosidade de um gênero que se objetifica sem ser espécie alguma definida, gênero que imediatamente se determina e que prenuncia a produção própria aos "indivíduos histórico-universais" de A ideologia alemã, não é apenas a afirmação de que o homem só age de maneira não alienada apenas quando age conscientemente como "ser social", ou seja, reconhecendo que sua essência é seu "ser social" genérico e historicamente determinado. Se assim o fosse, a afirmação da vida do gênero não seria nada mais que uma apropriação reflexiva da universalidade situada de minhas condições históricas, assim como da substância comum às relações intersubjetivas que me constituíram e que se expressa silenciosamente nos objetos que trabalho. O que nos levaria a uma especularidade muito bem descrita involuntariamente por Feuerbach ao falar, não por acaso, da especificidade da Gattungsleben humana:

43 Não será a última vez que Marx usará a potência de indeterminação do sujeito para construir um espaço de reconhecimento não-alienado. De certa forma, tal "ser sem espécie definida" adianta, do ponto de vista ontológico, a "classe dos desprovidos de classe" na qual Marx encontrará o proletariado, como veremos de maneira mais articulada na terceira parte deste livro.

$44 \mathrm{O}$ termo vem de Feuerbach que, ao procurar estabelecer distinções entre humanidade e animalidade, dirá: "De fato é o animal objeto para si mesmo como indivíduo - por isto ele tem sentimento de si - mas não como gênero - por isto, falta-lhe a consciência, cujo nome deriva de saber. Onde existe consciência existe também a faculdade para a ciência. A ciência é a consciência dos gêneros. Na vida, lidamos com indivíduos, na ciência com gêneros. Mas somente um ser para o qual seu próprio gênero, sua quididade, torna-se objeto, pode ter por objeto outras coisas ou seres de acordo com a natureza essencial deles" (FEUERBACH, Ludwig. A essência do cristianismo, Petrópolis: Vozes, 2007, p. 35). 
A bela imagem é contente de si mesma, tem necessariamente alegria de si mesma, reflete-se necessariamente em si mesma. Vaidade é apenas quando o homem namora sua própria forma individual, mas não quando ele admira a forma humana. Ele deve admirá-la; não pode conceber nenhuma forma mais bela, mais sublime que a humana. Certamente, todo ser ama a si mesmo, a sua essência, e deve amá-la ${ }^{45}$.

A vida do gênero é, nesta leitura, o que permitiria ao homem olharse no espelho e não ver sua forma individual, mas descobrir a beleza universal da forma humana, a substancialidade da forma. A analogia é sugestiva e dificilmente não seria atualmente completada com a pergunta: mas o que dizer se insistíssemos que, ao contrário, o homem é exatamente este ser que se perde ao olhar-se no espelho, que estranha sua imagem como quem vê algo prestes a se deformar, que não reconhece sua própria imagem por não ter uma forma essencial que lhe seja própria? O que dizer se aceitarmos que a experiência do espelho é confrontação com algo do qual não nos apropriamos por completo, mas que nos atravessa produzindo o sentimento de uma profunda impropriedade?

Esta é apenas uma maneira figurada de afirmar que a universalidade que passa à existência não pode existir como mais uma espécie, não pode se determinar tal como se determinam espécies particulares, como se disséssemos algo como: "existem cavalos, bois, abelhas e ... animais", pois não estamos diante de uma universalidade por partilha de atribuição. De certa forma, "animais" só podem vir à existência através da desarticulação do campo de determinações que permite a organização das diferenças predicáveis responsáveis pela particularização dos existentes. Neste sentido, estamos diante de uma universalidade por excesso em relação ao espaço da manifestação de particularidades. Esta é outra maneira de dizer que a universalidade não deve ser compreendida como determinação normativa capaz de definir, por si só, o sentido daquilo que ela subsume, mas como a força de descentramento da identidade autárquica dos particulares ${ }^{46}$. A universalidade é, neste contexto, apenas a generalização da impossibilidade do particular ser idêntico a si mesmo e a transformação desta impossibilidade em processo de constituição de relações. Aceitando tal conceito de universalidade, deveremos dizer que o trabalho que expressa a "vida do gênero" deve ser compreendido como a fonte inesgotável dos possíveis que passa à existência, mas sem nunca determinar-se por completo em um valor particular de uso totalmente

45 FEUERBACH, Ludwig, A essência do cristianismo, op. cit., p. 39

46 Desenvolvi melhor esta ideia, a propósito da leitura adorniana de Hegel, em SAFATLE, Vladimir: "Os deslocamentos da dialética" In: ADORNO, Theodor. Três estudos sobre Hegel, São Paulo: Unesp, 2013 
funcionalizado. Por isto, ela pode impulsionar os objetos trabalhados a uma processualidade sempre aberta de sentido sob a forma de devir contínuo. Processualidade que as obras de arte expressam em sua forma mais bem acabada.

\section{Gênero e genialidade estética}

Tal perspectiva talvez faça justiça de forma mais adequada à dimensão estética da reflexão marxista sobre o trabalho. De fato, podemos dizer que é como portador da vida do gênero que o sujeito trabalha segundo "as leis da beleza", pois as leis da beleza não são estas que fundam as formas humanas em uma arché, um pouco como a afirmação de Feuerbach parece nos levar a acreditar. Esta leitura seria necessariamente conservadora a respeito das questões próprias à forma estética e radicalmente defasadas mesmo diante do estado da crítica na estética romântica tardia à época de Marx. Mais correto seria afirmar que as leis da beleza são estas que se quebram diante da expressão do gênio, temática fundamental da estética romântica. Não por acaso, a raiz latina da palavra alemã Gattung é o latim genus e o grego génos. Genus partilha com genius a raiz gen que indica engendrar, produzir.

Giorgio Agamben tem um pequeno texto sobre o conceito de gênio que pode auxiliar nas consequências desta estética da produção a animar o jovem Marx e, como gostaria de defender, pressuposta mesmo no Marx da maturidade. Agamben lembra que os latinos chamavam Genius ao deus ao qual todo homem é confiado sob tutela na hora do nascimento, resultado da afinidade etimológica entre gênio e gerar. Por isto, Genius era, de uma certa forma, a divinização da pessoa, o princípio que rege e exprime toda sua existência. No entanto, Agamben faz questão de insistir a respeito de um ponto de grande importância para nós:

Mas esse deus muito íntimo e pessoal é também o que há de mais impessoal em nós, a personalização do que, em nós, nos supera e excede. 'Genius' é a nossa vida, enquanto não foi por nós originada, mas nos deu origem. Se ele parece identificar-se conosco, é só para desvelar-se, logo depois, como algo mais do que nós mesmos, para nos mostrar que nós mesmos somos mais e menos do que nós mesmos. Compreender a concepção de homem implícita em Genius equivale a compreender que o homem não é apenas Eu e consciência individual, mas que, desde o nascimento até a morte, ele convive com um elemento impessoal e pré-individual ${ }^{47}$.

$\overline{47}$ AGAMBEN, Giorgio. Profanações, São Paulo: Boitempo, 2010, p. 16. 
Ou seja, o que funda o gênio não é a expressão da singularidade irredutível da pessoa, mas é o que estará necessariamente ligado à maneira singular de lidar com a impropriedade de um elemento impessoal e pré-individual que habita todo e qualquer sujeito, o que não deixa de ressoar o fato de genius ter ligações também com genus, com este gênero impotente a se determinar como espécie do qual fala Marx. Assim, a expressão subjetiva só poder aparecer lá onde o artista saberá quebrar a regularidade da forma, fazendo circular o que força a linguagem em direção à não-comunicação. Sua genialidade estará ligada à capacidade de quebrar a regularidade sem desestruturar a forma por completo. Quebras que darão à forma sua tensão interna, que lembrarão à forma como ela estará sempre assombrada por algo de informe que parece insistir e dever encontrar lugar ${ }^{48}$.

Insistir na proximidade entre gênero e gênio, ao menos neste contexto, tem o mérito de permitir a posição de uma universalidade que se realiza na ação sem ser a expressão da partilha positiva de atributos gerais, como se estivéssemos a falar da condição de atribuição de elementos múltiplos a um mesmo conjunto. A vida do gênero é o advento de uma universalidade não-substancial, fundada na indeterminação que faz de toda essência uma atividade em reinscrição contínua de seus acontecimentos, e não um ser. Neste sentido, a expressão laboral de uma vida que é vida do gênero, Gattungsleben, só poderia se dar como problematização do objeto trabalhado enquanto propriedade especular das determinações formais da consciência, enquanto aquilo do qual a consciência se apropria por completo no interior de um plano construtivo ${ }^{49}$. A vida que se expressa como vida do gênero é o que nos libera das amarras das formas de

48 A história da sonata romântica é a problematização cada vez maior de seu desenvolvimento; é o melhor exemplo desta forma que flerta a todo momento com sua própria informidade. Para uma análise do desenvolvimento da forma sonata, ver ROSEN, Charles, Sonata forms, Nova York: W. W. Norton and Company, 1988.

49 Impossível não lembrar, neste contexto, do que um atento leitor de Marx, a saber, Theodor Adorno, afirmava a respeito da produção do objeto estético: "A possibilidade da arte não se transformar em um jogo gratuito ou em uma decoração depende da medida de suas construções e montagens serem, ao mesmo tempo, desmontagens, integrando, ao desorganizá-los, os elementos da realidade que associam-se livremente em algo diferente" (ADORNO, Äestetische Theorie, Frankfurt: Suhrkamp, 1973, p. 324). Pois a diferença entre a ordem reificada presente na realidade social e a instauração formal que toda verdadeira obra de arte é capaz de produzir está no fato de apenas a obra de arte reconhecer a tensão entre os princípios formais e o material que ela procura submeter. Um objeto estético não é apenas a realização de um plano construtivo que se apropria dos materiais à sua disposição. Ele é também a desorganização de tal plano a partir da resistência dos materiais, a cena no interior da qual o plano construtivo encontra seu limite. Uma obra de arte totalmente construída, incapaz de levar ao paroxismo a tensão entre forma e material, seria a monstruosidade da simples exemplificação de um estilo. Esta é uma maneira importante de lembrar que, na produção estética, o sujeito encontra o fracasso da objetivação de sua intenção primeira, condição constitutiva para a própria realização da obra de arte. 
determinação atual da consciência, de seus modos de apropriação, sem nos levar a uma universalidade que é apenas a figura da individualidade universalizada. Pois há de se aceitar a noção de que "o comum não é característica do próprio, mas do impróprio ou, mais drasticamente, do outro; de um esvaziamento - parcial ou integral - da propriedade em seu negativo; de uma desapropriação que investe e descentra o sujeito proprietário, forçando-o a sair de si mesmo"50. Por isto, a vida que se expressa como vida do gênero é o que há de impróprio em nós e o que permite ao trabalho aparecer como expressão do estranhamento enquanto afeto de relação do sujeito a si.

\section{A reconfiguração psíquica do mundo do trabalho}

Esta digressão em direção a certa leitura do problema do trabalho em Marx nos auxilia a compreender o sentido da mutação pela qual a estrutura disciplinar do mundo do trabalho passou nas últimas décadas. Ela também pode nos servir para identificar melhor as modalidades de sofrimento psíquico que tal mutação produziu, mostrando assim qual o quadro correto de compreensão de seu sentido social. Tal sofrimento pode ser compreendido, como gostaria de mostrar, como resultado da espoliação psíquica do estranhamento.

Notemos inicialmente que tal maneira de compreender as mutações do mundo do trabalho e seus impactos psíquicos anda na contramão das defesas do fim da sociedade do trabalho e da obsolescência do paradigma da produção ${ }^{51}$. Talvez seria mais correto ver, nela, a maneira com que as sociedades capitalistas avançadas procuraram absorver exigências de reconhecimento presentes no horizonte normativo do trabalho social. O núcleo ideológico mais avançado das sociedades capitalistas criou algo como um horizonte normativo do trabalho calcado na transformação de certas expectativas depositadas na crítica do trabalho em nova estrutura disciplinar. Partamos, a este respeito de um dos estudos mais importantes sobre as mutações do capitalismo contemporâneo, a saber, este desenvolvido pelos sociólogos Luc Boltanski e Eve Chiapello. Os dois afirmam que a natureza obsessivo-compulsiva do trabalho tematizado por Weber tenderia a desaparecer nas sociedades capitalistas contemporâneas graças ao advento de um "novo ethos do capitalismo" nas últimas décadas, ethos resultante da absorção do impacto dos movimentos de contestação a nossas formas hegemônica de vida, como os que vimos em maio de 1968. A partir de então:

50 ESPOSITO, Roberto. Communitas, op. cit., p. XIV.

51 Ver, por exemplo, Matthes, 1983. Para uma crítica a tal tese, ver Antunes, 1995. 
O sistema capitalista se revelou infinitamente mais robusto do que acreditavam seus detratores, Marx em primeiro lugar, mas isso também ocorreu porque ele encontrou em seus críticos mesmos os caminhos para a sobrevivência [...]. Foi, provavelmente, essa capacidade surpreendente de sobrevivência graças à assimilação de parte da crítica que contribuiu para desarmar as forças anticapitalistas $[\ldots]^{52}$.

Sabemos como uma das vertentes da crítica social que se desenvolve a partir de maio de 1968 visava o trabalho e sua incapacidade de dar conta de exigências de autenticidade. Visto como o espaço da rigidez do tempo controlado, dos horários impostos, da alienação taylorista e da estereotipia de empresas fortemente hierarquizadas, o trabalho fora fortemente desvalorizado pelos jovens de 68. Vários estudos do início dos anos setenta demonstram consciência dos riscos de uma profunda desmotivação dos jovens em relação aos valores presentes no mundo do trabalho, preferindo atividades flexíveis, mesmo que menos renumeradas. Um estudo publicado na França em 1975, pelo Centro de Estudos sobre o Emprego mostrava como

[...] o fato dos jovens não estarem inseridos em um trabalho e em um trabalho regular não era imputado à raridade dos empregos mas a uma maneira voluntária de evitar o trabalho assalariado por procurar um 'outro modo de vida', condições de trabalho que oferecessem maior flexibilidade nos horários e ritmos, 'combinações' transitórias que permitiam manter um comportamento desligado, distante em relação ao trabalho, o que lhes permitiam serem autônomos, livres, não submetidos a autoridade de um chefe (Idem, p. 252).

O resultado de tal crítica teria sido a reconfiguração do núcleo ideológico da sociedade capitalista e a consequente modificação do ethos do trabalho. Exemplo maior desta "capacidade de sobrevivência do capitalismo por endogeneização da crítica" são os valores como: segurança, estabilidade, respeito à hierarquia e à especialização, valores estes que o mundo empresarial trouxe de organizações como o exército e que compunham o núcleo de empresas paradigmáticas dos anos 50 e 60, como a IBM, deram lugar a um conjunto de valores vindos diretamente do universo de crítica do trabalho, universo não por acaso decalcado do que os autores chamam de "crítica artista" às formas capitalistas de vida, a saber, capacidade de enfrentar riscos, flexibilização, maleabilidade, desterritorialização resultante de processos infinitos de reengenharia; todos estes valores compõem atualmente um novo núcleo ideológico. Se ainda na década de sessenta, o profissional modelo era aquele capaz

52 BOLTANSKI; CHIAPELLO. O novo espírito do capitalismo, p. 69. 
de impor-se uma funcionalização de sua personalidade, aprimorando sua especialidade e habilidades até se transformar no corpo de um só órgão que descreve Marx, hoje ele seria visto como alguém acomodado, sem capacidade de se reinventar e, por isto, com baixa capacidade de inovação e criatividade. O manager modelo é atualmente descrito de outra forma:

O manager é o homem das redes. Ele tem por qualidade primeira sua mobilidade, sua capacidade de se deslocar sem se deixar prender por fronteiras - sejam geográficas ou derivadas de ligações profissionais ou culturais -, por diferenças hierárquicas, de estatuto, de papel, de origem, de grupo, assim como sua capacidade de estabelecer um contato pessoal com outros atores, geralmente muito distantes socialmente ou espacialmente (Idem, p. 123).

Este é um exemplo do esgotamento da ética do trabalho derivada do protestantismo e do advento de um modelo de ética do trabalho derivada da produção estética. Pois esta desterritorialização própria ao manager não deixa de mobilizar valores próprios àqueles que não tinham lugar fixo no interior da estratificação social, ou seja, a boemia artista. ${ }^{53} \mathrm{~A}$ personalidade rígida e assombrada pelo autocontrole sai para dar lugar a identidades flexíveis. Daí porque Boltanski e Chiapello falam da absorção de uma "crítica artista" pelo capitalismo.

Nós encontramos algo similar a esta absorção no conceito de "trabalho imaterial" desenvolvido pelo sociólogo André Gorz para dar conta da configuração atual do mundo do trabalho. Ao menos segundo Gorz, estaríamos atualmente em uma época na qual o trabalho não deveria mais ser compreendido como a produção de objetos previamente definidos, mas como a gestão contínua de fluxos de informação vindos da vida concreta, da interação comunicacional que permitira uma produção cada vez mais customizada e maleável às mudanças, isto na esteira da obsolescência do taylorismo e da hegemonia do toyotismo. Por isto:

O trabalho não é mais mensurado por normas e padrões pré-estabelecidos. Não podemos mais definir tarefas objetivamente. A performance não é mais definida em relação a tarefas, mas implica diretamente pessoas [...] Da mesma forma que as tarefas a serem realizadas não podem ser formalizadas, elas não podem ser prescritas [...] Como é impossível medir performances individuais e prescrever procedimentos para se chegar a um resultado particular, managers devem recorrer à 'gestão por objetivos' (GORZ, 2010, p. 8).

53 Ver a este respeito os ensaios de Paulo Arantes (1996) sobre a boemia artista na França pré-revolucionária. 
Nesta circunstância na qual a produção não seria mais vista como produção de objetos, mas como produção do imaterial, ou seja, de serviços, "experiências", valores e "acesso", os trabalhadores necessitariam de "capacidades expressivas e cooperativas que não podem ser ensinadas, da vivacidade no desenvolvimento de um conhecimento que é parte da cultura da vida cotidiana" (GORZ, 2010, p. 9) ${ }^{54}$. Esta é uma maneira de afirmar que estaríamos diante de uma atividade laboral que teria se reconciliado com a vida, ou seja, com a capacidade da vida produzir a si mesma. As empresas apenas canalizariam tal capacidade. O horizonte perfeito aconteceria então quando o próprio trabalho assalariado desaparecesse para que os trabalhadores se transformassem em empresas. "Pessoas devem se transformar em empresas de si mesmos" (p. 19), empresas que se associam a outras empresas em dinâmicas flexíveis administradas por organizações que, a partir de então, teriam apenas funcionários terceirizados.

Gorz sabe como esta visão de paraíso neoliberal da desregulamentação absoluta ignora o impacto dos sentimentos de insegurança, descontinuidade do trabalho e precarização advinda de períodos de inatividade, de onde se segue sua ideia de exigir que o Estado ofereça algo como uma renda mínima independente de todo e qualquer emprego. No entanto, isto não muda um ponto fundamental na proposta de reconciliação entre as exigências de reconhecimento e as potencialidades do trabalho no estágio atual do desenvolvimento das sociedades de capitalismo avançado. Note-se que não se trata aqui de discutir em até que ponto a dimensão efetiva do trabalho na sociedade capitalista contemporânea, com sua "dinâmica dupla de intensificação e de precarização do trabalho" 55 , pode ser descrita da forma proposta

54 Isto levará Negri e Hardt a afirmar que "o trabalho imaterial envolve de imediato a interação e a cooperação sociais. Em outras palavras, o aspecto cooperativo do trabalho imaterial não é imposto e organizado à força, como ocorria em formas anteriores de trabalho, mas a cooperação é totalmente imanente à atividade laboral. [...] Na expressão de suas próprias energias criativas, o trabalho imaterial parece, dessa forma, fornecer o potencial de um tipo de comunismo espontâneo e elementar" (NEGRI, Antonio e HARDT, Michael. Império, Rio de Janeiro: Record, 2006, p. 314).

55 RENAULT, Emmanuel. Souffrance sociale: philosophie, psychologie et politique, Paris: La Decouverte, 2008, p. 396. Lembremos ainda como a flexibilização do trabalho significou, de fato, "liberdade da empresa para desempregar trabalhadores sem penalidades, quando a produção e as vendas diminuem, liberdade, sempre para a empresa, para reduzir o horário de trabalho ou de recorrer a mais horas de trabalho, possibilidade de pagar salários reais mais baixos do que a paridade de trabalho exige; possibilidade de subdividir a jornada de trabalho em dia e semana segundo as conveniências das empresas, mudando os horários e as características do trabalho (por turno, por escala, em tempo parcial, horário flexível etc.), dentre tantos outras formas de precarização da força de trabalho" (ANTUNES, Ricardo. "Século XXI: nova era da precarização estrutural do trabalho?" In: ANTUNES, Ricardo; BRAGA, Ruy. Infoproletários: degradação real do trabalho virtual, São Paulo: Boitempo, 2009, p. 234). 
por Gorz. Mais importante do que isto é compreender como valores e processos como os descritos por Gorz transformaram-se no horizonte regulador que guia as expectativas daqueles que entram atualmente no mundo do trabalho. Mesmo que a degradação das condições de trabalho e a precarização sejam realidades bastante concretas, isto a ponto de podermos falar de um retorno à forma primitiva de extração do maisvalor - o mais-valor absoluto produzido pelo aumento da quantidade de trabalho e pela redução do salário real ${ }^{56}$-, não é desprovido de interesse lembrar como o núcleo ideológico do mundo do trabalho se reconfigurou a partir de valores que, há até bem pouco tempo, serviam de esteio para a crítica do trabalho nas sociedades capitalistas.

\section{Considerações finais: sofrimento de flexibilização}

Diante disto, temos duas saídas possíveis: a primeira consistiria em admitir que as modalidades de crítica do trabalho apresentadas não oferecem um horizonte muito distinto daquele já sintetizado pelas sociedades capitalistas mais avançadas. A desregulação neoliberal do trabalho apareceria como produção de formas de recusa à estrutura disciplinar das identidades, isto através de suas flexibilizações. Neste sentido, não caberia outra coisa que denunciar o descompasso entre promessas presentes no horizonte normativo do setor mais avançado do capitalismo contemporâneo e sua realização, fazendo uma espécie de crítica imanente que compara a realidade a seu próprio conceito. $\mathrm{O}$ preço a pagar é aceitar que todo o potencial de transformação social já está presente em potência, isto é, já foi pensado em suas figuras pela própria sociedade capitalista; não há realidade alguma distinta do que já está enunciado como possibilidade.

O outro caminho consistiria em estar atento para qual tipo de sofrimento psíquico que tais paraísos neoliberais de desregulação e identidades flexíveis realmente produziram, que tipo de afetos eles foram capazes de fazer circular. Este segundo caminho se justifica se aceitarmos que uma sociedade não define apenas sistemas de normas a serem seguidos, ela define principalmente modos de sofrimento diante das normas que ela mesma enuncia quando gere tais modos em um quadro tacitamente aceito de patologias, com suas estratégias de encaminhamento clínico, com suas montagens de sintomas e complexos. Uma sociedade é, acima de tudo, uma forma de produção de patologias, ou seja, de tradução do sofrimento na gramática ordenada de patologias. Uma gramática que será constantemente mobilizada a fim de fornecer

56 RENAULT, Emmanuel, idem, p. 397. 
ao sofrimento um encaminhamento terapêutico socialmente aceito. Desta forma, a questão fundamental para a reprodução social não é a determinação impositiva da normalidade, mas a organização diferencial das patologias possíveis. É assim que uma sociedade controla suas margens, as mesmas margens a partir das quais poderiam vir demandas de transformação.

Se aceitarmos tal perspectiva, faz-se necessário estar atento a um paralelismo instrutivo. No mesmo momento em que o universo do trabalho passava por profunda reconfiguração devido à flexibilização neoliberal, formas de sofrimento psíquico como as depressões e transtornos de personalidade como as patologias narcísicas e borderline apareciam cada vez mais dominantes ${ }^{57}$. A este respeito, lembremos que, segundo a Organização Mundial da Saúde (OMS), 7\% da população mundial sofria de depressão em 2010, sendo a principal causa conhecida o sofrimento psíquico. Em países como o Reino Unido, 1 em cada 5 adultos sofre atualmente de depressão. Os casos de depressão crescem em média $20 \%$ ao ano em países como os EUA, onde $9,1 \%$ da população sofre da doença, e representam, atualmente, a modalidade de sofrimento psíquico com maior impacto econômico ${ }^{58}$.

Temos o direito de nos perguntar se tal paralelismo temporal não guardaria articulações profundas entre si. Em que sentido seria possível afirmar que modificações no universo do trabalho foram fatores importantes para o crescimento de certos quadros de patologias psíquicas? Não se trata aqui de perguntar se o sofrimento no mundo do trabalho se manifesta tendencialmente sob a forma de transtornos depressivos, mas trata-se, antes, de indicar como as formas de conflito produzidas pelo impacto psíquico do mundo do trabalho são atualmente geridas, entre outras estratégias, pela constituição de quadros clínicos capazes de individualizar dinâmicas de sofrimento cuja estrutura causal mascaram a possibilidade de compreensão das relações profundas entre sofrimento social e psíquico.

Se procurarmos a definição psiquiátrica dos transtornos depressivos encontraremos descrições como: "a característica comum de todos estes

${ }^{57}$ Sobre esta historicidade da depressão, vale a pena sublinhar que "quando surgiu o primeiro antidepressivo, em 1956, o laboratório Geigy, que o sintetizou, chegou a hesitar em comercializá-lo, pois considerava o mercado da depressão insignificante. Na verdade, a imipramina foi inicialmente sintetizada pela Geigy para ser um antipsicótico, tendo uma estrutura química bastante semelhante à da clorpromazina, do laboratório concorrente RhônePoulenc. Só a esquizofrenia, que abrangia $1 \%$ da população, interessava como mercado para a indústria farmacêutica" (AGUIAR, Adriano. A psiquiatria no divã: entre as ciências da vida e a medicalização da existência, Rio de Janeiro: Relume Dumará, 2004, p. 94).

58 Ver: <http://www.nimh.nih.gov/health/statistics/prevalence/major-depression-among-adults. shtml>. 
transtornos é a presença de humor ligada a sentimentos de tristeza, esvaziamento, irritação acompanhado de modificações somáticas e cognitivas que afetam de forma significativa a capacidade individual para funcionar (to function - um termo sintomático por denunciar demanda por desempenho)"59. Tais transtornos, descritos sem levar em conta perspectiva etiológica alguma, devem durar ao menos duas semanas envolvendo modificações sensíveis nos afetos, na cognição e em funções neurovegetativas, sendo atualmente divididos em categorias como: transtornos de desregulação de humor, transtornos depressivos maiores, distimia, transtornos de disforia pré-menstrual, transtornos depressivos induzidos por medicamentos e outras substâncias, induzidos por outras condições médicas e transtornos depressivos não especificados. $O$ quadro comum destes transtornos é constituído por sintomas recorrentes como: perda significativa de interesse e prazer em todas ou quase todas atividades, insônia ou hipersonia, cansaço ou perda de energia durante todo o dia, sentimentos de inutilidade, baixa estima ou culpa excessiva, modificação brusca de apetite, diminuição da capacidade de concentração e pensamentos mórbidos.

Até 1994, o DSM reconhecia apenas dois tipos de transtornos depressivos: o transtorno depressivo maior e a distimia, ambos compreendidos como formas de transtornos afetivos particularizados a partir de 1980 (ano de publicação do DSM III), momento em que a atenção clínica à depressão conhece substancial crescimento. Até então, a depressão passara por um processo através do qual ela deixara de ser apenas a descrição de um polo de reações no interior de uma patologia bipolar maníaco-depressiva (como era o caso em Kraepelin no final do século XIX) ou no quadro geral das neuroses. Com a publicação do DSM II, em 1968, ela aparece como "neurose depressiva", deixando de ser compreendida como reação depressiva neurótica enquanto termo geral para depressão não-bipolar, isto quando não era caracterizada como "depressão endógena" (causada por fatores eminentemente biológicos e caracterizada por ausência de causas exógenas). Por fim, a partir do final dos anos setenta, ela ganhará autonomia em relação ao quadro, agora abandonado, das neuroses.

Tal dissociação entre depressão e o quadro das neuroses, com sua herança psicanalítica, não é um mero ajuste nosográfico ocorrido, por coincidência, exatamente no momento de imposição da guinada neoliberal nos países capitalistas centrais, já que 1980 é o momento inicial de impulsão do neoliberalismo como política de Estado. $\mathrm{Na}$ verdade, a neurose e depressão são modelos radicalmente distintos

59 AMERICAN PSYCHIATRIC ASSOCIATION; DSM - V, Arligton: APA, 2013, p. 155. 
de patologias. Como viu claramente Alain Ehrenberg (2000, p. 10), a depressão só pode aparecer como problema central no momento em que o modelo disciplinar de gestão de condutas cede lugar a normas que incitam cada um à iniciativa pessoal, à obrigação de ser si mesmo. Pois contrariamente ao modelo freudiano das neuroses, onde o sofrimento psíquico gira em torno das consequências de internalização de uma lei que socializa o desejo organizando a conduta a partir da polaridade conflitual permitido/proibido, na depressão tal socialização organizaria a conduta a partir de uma polaridade muito mais complexa e flexível, a saber, a polaridade possível/impossível ${ }^{60}$. A proibição moral advinda das exigências normativas de socialização dá lugar a uma situação de flexibilização das leis, de gestão da anomia que coloca as ações não mais sob o crivo da permissão social, mas sob o crivo individual do desempenho, da performance, da força relativa à capacidade de sustentar demandas de satisfação irrestrita. Assim, o indivíduo é confrontado a uma patologia da insuficiência e da disfuncionalidade da ação, ao invés de uma doença da proibição e da lei. Se a neurose é um drama da culpabilidade, drama ligado ao conflito perpétuo entre duas normas de vida, a depressão aparece como tragédia implosiva da insuficiência e da inibição.

A este respeito, lembremos como o paradigma assentado na ética protestante do trabalho ascético, com sua formação em direção à autonomia, era inseparável do desenvolvimento de um sentimento neurótico de culpabilidade e de uma dinâmica de organização psíquica assentada na clivagem, na repressão e no recalque. Um dos pontos principais desse processo estava claramente tematizado por Freud através de sua teoria do superego. Não se tratava simplesmente de dizer que o fracasso nas dinâmicas de reconhecimento através do trabalho provocaria sentimento neurótico de culpabilidade, motor para a estereotipia, rigidez e estaticidade de papéis que definiam as identidades no interior do mundo do trabalho taylorista. Na verdade, a ideia consistia em afirmar que não era possível ser bem-sucedido em processos de reconhecimento social através do trabalho sem se confrontar com este "saldo patológico" que Freud descreveu tão bem graças à sua teoria das neuroses baseada nos vínculos produzidos pela culpabilidade.

Da mesma forma, a reconfiguração do universo do trabalho através dos imperativos de flexibilização e desempenho não são sem produzir um

60 "O direito de escolher sua vida a e injunção a advir de si mesmo colocam a individualidade em um movimento permanente. Isto leva a colocar de outra forma o problema dos limites reguladores da ordem interior: a partilha entre o permitido e o proibido declina em prol de um esgarçamento entre o possível e o impossível" (EHRENBERG, 2000, p. 15). 
saldo patológico inexorável ${ }^{61}$. Já deve estar claro como a reconfiguração do mundo do trabalho descrita neste capítulo inspirou-se em uma modalidade muito específica de recuperação de exigências de expressão esquecidas no interior das sociedades capitalistas avançadas. Tal realização de exigências de expressão foi capaz de aproximar as dinâmicas do trabalho daquilo que "não é previamente mensurado"; "não se submete integralmente ao plano", mas absorve-se o risco, a instabilidade e a indeterminação.

Assim, se anteriormente o sentimento de alienação no trabalho estava vinculado à perda da autenticidade na esfera da ação, com as temáticas clássicas da estereotipia inflexível das normatividades e da perda da individualidade, atualmente nos deparamos com a crença que cabe apenas ao indivíduo a responsabilidade pelo fracasso da tentativa de autoafirmação de sua individualidade no interior do trabalho, pois o próprio discurso social é constituído a partir da incitação à autoexpressão de si. O que nos faz acreditar que, se tal autoexpressão não se realizou, foi por culpa única a exclusiva da covardia moral do indivíduo incapaz de afirmar suas múltiplas possibilidades no interior da "sociedade de risco". Devemos falar em "covardia" neste contexto porque "risco", tal como ele é empregado pelos teóricos da modernização reflexiva é, acima de tudo, uma categoria moral. Isto talvez explique porque, atualmente, o processo de desregulamentação neoliberal do mundo do trabalho foi respondido com a "privatização de reações de recusa e ausência de indignação pública". Honneth chega a falar, com propriedade:

Parece que estamos atualmente inclinados a privatizar nosso descontentamento, como se fôssemos nós mesmos responsáveis pelo desemprego iminente ou pela transferência anunciada. Talvez seja esta impressão, o sentimento de ser o único responsável por seu destino profissional, que explica também o silêncio opressivo que acolhe atualmente todos os recuos registrados na esfera do trabalho social em termos de garantias e de flexibilização ${ }^{62}$.

61 Pois, como bem compreendeu Boltanski e Chiapello (1999, p. 152): "A taylorização do trabalho consiste em tratar seres humanos como máquinas. Mas o caráter rudimentar dos métodos utilizados não permite colocar a serviço da procura do lucro as propriedades mais humanas dos seres humanos, seus afetos, sentimentos morais, honra, capacidade de invenção. Ao contrário, os novos dispositivos que pedem um engajamento mais completo e se apoiam em ergonomias mais sofisticadas, integrando contribuições da psicologia pós-behaviorista e das ciências cognitivas, exatamente por serem mais humanos, penetram mais profundamente na interioridade das pessoas, das quais se espera que "se entreguem" a seu trabalho e tornem possível uma instrumentalização dos homens naquilo que eles têm de propriamente humanos".

62 HONNETH, Axel. O direito da liberdade, p. 385. 
Notemos, no entanto, como esta promessa de expressão de si é baseada em uma forma específica de espoliação. O paradoxo atual encontra-se no fato de que se produz sob a forma capitalista sem a imposição disciplinar que lhe foi normalmente associada. A expressão no trabalho deve se conformar ao processo de produção de valor, a objetificação sob a formamercadoria e seus imperativos de produtividade, sem ser necessário apelar às estruturas disciplinares impositivas próprias à ética do trabalho com suas dinâmicas repressivas. Neste sentido, a disciplina parece moldarse à própria dinâmica das pulsões, já que se garantiu que a produção sempre será igual, que os objetos sempre serão suportes de determinação de valor $^{63}$. O princípio de produtividade e produção de valor, uma vez garantidos, permite uma ampla flexibilização dos modos de disciplina. Por isto, podemos dizer que a espoliação aqui não é apenas do maisvalor, mas do estranhamento vindo dos objetos trabalhados. Como não há negatividade que possa circular na relação entre o sujeito e o produto de suas ações - pois entre o sujeito e seu produto deve imperar uma pura afirmação - a reação à forma de determinação dos objetos do trabalho só pode se dar sob a forma de recusa depressiva. Uma saída socialmente perfeita leva-nos a crer que, atualmente, a única forma de manifestação da negatividade é a implosão depressiva. Desta forma, a depressão tornou-se um setor fundamental da estrutura disciplinar contemporânea. Ela fornece a figura contemporânea para a ideia, defendida no primeiro capítulo, segundo a qual as identificações nas quais o poder se assenta agem em nós produzindo afecções melancólicas. O poder introjeta suas injunções nos afetando depressivamente.

Lembremos, a este respeito, como a depressão descreve muito bem esta situação na qual me volto contra as escolhas de meu desejo, contra os modelos de minha forma de vida sem, no entanto, ser capaz de articular normatividades alternativas, ou seja, perpetuando o vínculo a uma normatividade que reitera continuamente minha impotência em assumir injunções gerais de gozo. Aparece assim uma consequência psíquica da absorção pelo mundo do trabalho dos próprios valores mobilizados na crítica da alienação. O sentimento de sofrimento em relação ao trabalho fica sem enunciação normativa. Parece não haver outras palavras para descrever aquilo que o trabalho não realiza ${ }^{64}$. Se o trabalho parece se

63 "Os modos de regulação e dominação da força de trabalho apoiam-se menos sobre a obediência mecânica do que sobre a iniciativa: responsabilidade, capacidade a evoluir, formar projetos, motivação, flexibilidade, etc., desenham uma nova liturgia de gestão. O controle imposto ao operário não é mais aquele do homem-máquina do trabalho repetitivo, mas o do empreendedor do trabalho flexível" (EHRENBERG, 2000, p. 234).

${ }^{64}$ Lembremos a este respeito do que diz o psicanalista Pierre Fedida (1998): "A depressão é uma doença da forma, sendo o psíquico o que dá forma ao humano. Sinto-me desfeita em minha aparência humana, diz uma mulher no momento em que se descreve". 
aproximar do jogo - vide todas as "técnicas de motivação" que procuram transformar as exigências de intensificação do trabalho em "gincanas" na qual aqueles que não cumprem metas "pagam prendas" humilhantes, mas feitas como se estivéssemos em uma brincadeira - da expressão de si e da hiperexcitação contínua da festa, o que dizer da recusa e do cansaço em expressar a si mesmo? Neste sentido, o sentimento melancólico de perda e de autoestima destruída próprios à depressão transformam-se na forma socialmente avalizada de vínculo a uma norma social fundada na incitação superegóica ao gozo ${ }^{65}$, e não mais na internalização da necessidade da repressão66. Colocar-se na posição depressiva é uma forma de sustentar uma norma que não pode ser realizada, embora deva ser fantasmaticamente sustentada. É uma forma de sustentar uma norma que me oprime por transformar o gozo em uma injunção pronta para ser realizada, impedindo toda consolidação de dinâmicas de conflito.

Por isto, tal vínculo à norma tem como uma de suas manifestações preferenciais a atomização do tempo em um conjunto desconexo de instantes desprovidos de tensão e relação. Em uma fórmula feliz de Maria Rita Kehl pode-se ler: "o tempo morto do depressivo funciona como refúgio contra a urgência das demandas de gozo do Outro"67. A negatividade contra um desempenho em fluxo contínuo elevado à condição de motivo de gozo vai, preferencialmente, em direção ao "refúgio" de um tempo morto. Tempo desconexo no qual "dois anos passam rápido, difícil é passar dois minutos" 68 . De toda forma, não deixa de ser sintomático que, no momento em que a vida social coloca em circulação o discurso do fim da era dos conflitos, como se não pudéssemos mais ler os impasses de nossa forma de vida a partir da dinâmica de conflitos sociais entre, por exemplo, trabalho/expressão de si, o universo da saúde mental deparase com uma patologia resultante da impossibilidade de a vida psíquica agenciar temporalmente contradições sob a forma do conflito.

Certamente, este quadro vale também para transtornos de personalidade extremamente disseminados em nossas sociedades ocidentais, como o transtorno de personalidade borderline: uma espécie de versão dos impasses depressivos onde a passividade depressiva invertese em atividade desesperada que, através do flerte contínuo com o risco, visa aproximar-se do impossível ${ }^{69}$; uma atividade, como lembra

\footnotetext{
65 A este respeito, ver SAFATLE, Vladimir; Cinismo e falência da crítica, São Paulo: Boitempo, 2008.

66 Sobre o vínculo entre depressão e sentimento de perda, ver BECK, Aaron, Cognitive theorapy and the emotions disorders, Londres: Penguin, 1976.

67 KEHL, Maria Rita. O tempo e o cão: a atualidade das depressões, São Paulo: Boitempo, 2009, p. 21.

68 Idem, p. 67.

69 Para os transtornos de personalidade boderline, ver Kernberg, 1975.
} 
Kernberg, marcada pela predominância de mecanismos primitivos de defesa do $\mathrm{Eu}$, de falta de tolerância à ansiedade, falta de controle dos impulsos e falta de canal de desenvolvimento sublimatório.

Foi desta forma, foi mobilizando tais transformações do sofrimento psíquico em patologias, que a inteligência dos Citas que lutavam contra seus escravos chegou até nossos Departamentos de Recursos Humanos.

\section{Referências}

AGAMBEM, Giorgio. A potência do pensamento: ensaios e conferências. Belo Horizonte: Autêntica, 2015.

AGUIAR, Adriano. A psiquiatria no divã: entre as ciências da vida e a medicalização da existência. Rio de Janeiro: Relume Dumará, 2004.

BATAILLE, Georges. O erotismo. Belo Horizonte: Autêntica, 2013.

A parte maldita, precedida de "A noção de dispêndio". Belo Horizonte: Autêntica, 2013.

BECK, Aaron. Cognitive theorapy and the emotions disorders, Londres: Penguin, 1976.

ESPOSITO, Roberto. Communitas: origine e destino della comunitá, Turim: Einaudi, 1998.

FAUSTO, Ruy. Marx: lógica e política - tomo II: Investigações para uma reconstituição do sentido da dialética. São Paulo: Brasiliense, 1987.

FOUCAULT, Michel. Surveiller et punir. Paris: Gallimard, 1975.

. Histoire de sexualité - vol I. Paris: Gallimard, 1978.

FREUD, Sigmund. "Die Traumdeutung". In: Gesammelte Werke - vol. II/III. Frankfurt: Fischer, 1999.

HABERMAS, Jürgen. Conhecimento e interesse. Rio de Janeiro: Tempo Brasileiro, 1976.

HEGEL, G. W. F. Fenomenologia do Espírito. Petrópolis: Vozes, 1992.

HERODOTO. História. Brasília: Editora da UnB, 1985.

ILLOUZ. O amor nos tempos do capitalismo. Rio de Janeiro: Zahar, 2011.

KEHL, Maria Rita. O tempo e o cão: a atualidade das depressões. São Paulo: Boitempo, 2009.

LOCKE, John. Two treatises of government. Cambridge: Cambridge University Press, 1988.

LUKÁCS, György. História e consciência de classe. São Paulo: Martins Fontes, 2002.

MARX, Karl. A ideologia alemã. Rio de Janeiro: Civilização Brasileira, 2007. . O Capital - vol. I. São Paulo: Boitempo, 2013.

. Das Kapital I. Berlin: Dietz Verlag, 1983.

. Grundrisse. São Paulo: Boitempo, 2011.

. Manuscritos econômico-filosóficos. São Paulo: Boitempo, 2004. 
MORGAN. Imagens da organização. São Paulo: Atlas, 1996.

POSTONE, Moishe. Tempo, trabalho e dominação social. São Paulo: Boitempo, 2014. SAFATLE, Vladimir. O dever e seus impasses. São Paulo: Martins Fontes, 2013.

. Grande Hotel Abismo: por uma reconstrução da teoria do reconhecimento. São Paulo: Martins Fontes, 2012.

. A paixão do negativo: Lacan e a dialética. São Paulo: Unesp, 2006.

SCHMIDT, Alfred. The concept of nature in Marx. Londres: Verso, 2014.

WEBER, Max. A ética protestante e o espírito do capitalismo. São Paulo: Companhia das Letras, 2001.

\section{Endereço postal:}

Departamento de Filosofia

Universidade de São Paulo - USP

Data de recebimento: 30/03/2015

Data de aceite: 09/04/2015 